\title{
Analisis Mengelola Sampah Rumah Tangga di Kecamatan Rantepao Kabupaten Toraja Utara
}

\author{
Yadiadwan Sampebua ${ }^{1)}$, Nurlita Pertiwi ${ }^{1)}$, Muzaki ${ }^{2)}$ \\ ${ }^{1)}$ PPs Kependudukan dan Lingkungan Hidup, Universitas Negeri Makassar \\ ${ }^{2)}$ Manajemen Informatika, STMIK Handayani Makassar \\ Email : yadisampebua1290@gmail.com
}

\section{(c) (1) (8)}

(C) 2020 - UEJ Program Studi Pendidikan Kependudukan dan Lingkungan Hidup

Universitas Negeri Makassar. Ini adalah artikel dengan akses terbuka

dibawah Licensi CC BY-NC-4.0(http:/creativecommons.org/licenses/by-nc/4.0)

\begin{abstract}
Abstrak.
Toraja Utara merupakan salah satu daerah tujuan wisatawan, sehingga menjadi salah satu daerah objek wisata yang berdampak terhadap perkembangan jumlah masyarakat dan menjadi dasar pertambahan jumlah sampah yang dihasilkan setiap harinya. Akibat dari jumlah sampah yang dihasilkan setiap hari dapat menjadi masalah lingkungan dan kesehatan. Penelitian ini bertujuan Untuk mengetahui hubungan antara tingkat pendidikan lingkungan hidup, sikap lingkungan hidup, dengan perilaku secara sendiri dan bersama-sama masyarakat mengelola sampah rumah tangga di Kecamatan Rantepao Kabupaten Toraja Utara. Jenis penelitian yang digunakan ialah penelitian kuantitatif dengan analisis statistik deskriptif yang menggunakan tiga variabel bebas dan satu variabel terikat yang berjumlah 100 orang. Instrumen yang digunakan adalah observasi, kuisioner dan dokumentasi. Hasil analisis data menunjukkan bahwa persentase sumbangan pengaruh pengetahuan, sikap, dan tingkat pendidikan terhadap perilaku mengenai pengelolaan sampah rumah tangga di wilayah Kecamatan Rantepao Kabupaten Toraja Utara sebesar $68,9 \%$.
\end{abstract}

Kata Kunci: Pengelolaan sampah, Rumah tangga, Kuantitatif,

Uji determinasi, Korelasi, Toraja Utara.

\section{PENDAHULUAN}

Kabupaten Toraja Utara merupakan salah satu daerah tujuan wisatawan, sehingga menjadi salah satu daerah objek wisata yang berdampak terhadap perkembangan jumlah penduduk. Meningkatnya jumlah penduduk pendatang dan aktivitas yang dilakukan untuk meningkatkan pertumbuhan ekonomi akan berpengaruh terhadap meningkatnya volume sampah Kabupaten Toraja Utara. Apabila masalah ini tidak dilakukan perubahan dalam penanganannya, baik teknis maupun kebijakan politis, dalam 
waktu dekat diprediksi dapat mengakibatkan terjadinya pencemaran lingkungan yang cukup signifikan di seluruh wilayah, baik langsung maupun secara tidak langsung.

Dari data survey EHRA (Environmental Health Risk Assasment) untuk pengelolaan sampah rumah tangga di Kabupaten Toraja Utara, sebesar 57\% sampah dibakar dan masih ada 29\% dibuang ke lahan kosong/kebun/hutan dan dibiarkan membusuk serta sebesar 5,5\% Dibuang ke sungai/kali. Sedangkan untuk praktik pemilahan sampah rumah tangga hanya sebesar 8,7\%. Dari segi volume dan karakteristik sampah volume timbulan sampah rumah tangga di Toraja Utara sekitar $\pm 94 \mathrm{~m}^{3} /$ hari. Pada skala kabupaten dapat dilihat bahwa presentase sampah rumah tangga yang mengalami banjir di Kabupaten Toraja Utara, tergolong sangat kecil yaitu berkisar 1,2\% dan lamanya genangan hanya berkisar $1 \mathrm{~s} / \mathrm{d} 3$ jam. Melihat kondisi dan data yang ada maka perlu adanya suatu kajian yang pasti dalam menganalisa pengelolaan sampah dan penyediaan fasilitas sarana dan prasarana pengelolaan sampah di Kabupaten Toraja Utara, sehingga dapat mengurangi masalah sampah yang dihasilkan Kabupaten Toraja Utara. Masalah lain lagi yang sering muncul dalam penanganan sampah di Toraja Utara adalah tingkat kesadaran masyarakat yang masih rendah untuk tidak membuang sampah pada kawasan bantaran sungai. Dikarenakan semakin sulitnya ruang yang pantas untuk pembuangan sampah dan pengangkutan sampah yang kurang baik dikawasan studi sehingga masyarakat membuang sampah ke bantaran sungai, kurangnya sarana dan prasarana pendukung persampahan dan biaya operasional sampah yang tinggi mengakibatkan masyarakat membuang sampah sembarangan tidak terkecuali ke sungai.

Untuk mendukung hal tersebut maka diperlukan suatu cara pengelolaan sampah yang berwawasan lingkungan melalui perencanaan yang matang dan terkendali dalam bentuk pengelolaan sampah yang terpadu dengan menggunakan konsep 3R Reduce (menggunakan kembali), Reuse (mengurangi), Recycle (daur ulang) serta dibutuhkan kerjasama antara pemerintah dan masyarakat dalam pembuangan dan pengelolaan sampah. Pembuangan dan pengelolaan sampah baik dalam pengurangan produksi smpah maupun penanganannya. Dalam pengelolaan sampah bukan hanya dititikberatkan pada pemerintah saja, namun diperlukan kesadaran dan kemandirian dari masyarakat sehingga diharapkan dapat tercapainya suatu sistem persampahan yang baik dan tidak merusak lingkungan.

Tujuan umum penelitian ini adalah Untuk mengetahui hubungan antara tingkat pendidikan lingkungan hidup, sikap lingkungan hidup, dengan perilaku secara sendiri dan bersama-sama masyarakat mengelola sampah rumah tangga di Kecamatan Rantepao Kabupaten Toraja Utara.

\section{METODE PENELITIAN}

Jenis penelitian yang digunakan ialah penelitian kuantitatif dengan pendekatan korelasional. Pendekatan korelasional bertujuan Untuk mengetahui hubungan antara tingkat pendidikan lingkungan hidup, sikap lingkungan hidup, dengan perilaku secara sendirisendiri dan bersama-sama masyarakat mengelola sampah rumah tangga di Kecamatan Rantepao Kabupaten Toraja Utara. Hasil penelitian ditampilkan dalam bentuk tabel distribusi. 


\section{HASIL DAN PEMBAHASAN}

\section{A. Tingkat Pendidikan}

Berdasarkan data yang diperoleh dari 100 responden diketahui terdapat 1 responden yang yang tidak tamat $\mathrm{SD}, 11$ responden yang tamat $\mathrm{SD}, 32$ responden yang tamat SMP/Sederajat, 41 responden yang tamat SMA/Sederajat, dan sisanya sebanyak 15 responden tamat perguruan tinggi. Untuk lebih jelasnya dapat dilihat pada Tabel 1 berikut:

Tabel 1. Distribusi Frekuensi Berdasarkan Tingkat Pendidikan

\begin{tabular}{cccc}
\hline No & Pendidikan & Frekuensi (Responden) & Persentase (\%) \\
\hline 1. & Tidak Tamat SD & 1 & $1 \%$ \\
\hline 2. & Tamat SD & 13 & $13 \%$ \\
\hline 3. & Tamat SMP/Sedejajat & 35 & $35 \%$ \\
\hline 4. & Tamat SMA/Sederajat & 39 & $39 \%$ \\
\hline 5. & Tamat Perguruan Tinggi & 12 & $12 \%$ \\
\hline
\end{tabular}

Berdasarkan tabel distribusi frekuensi di atas dapat disajikan dalam bentuk grafik histogram sebagai berikut:

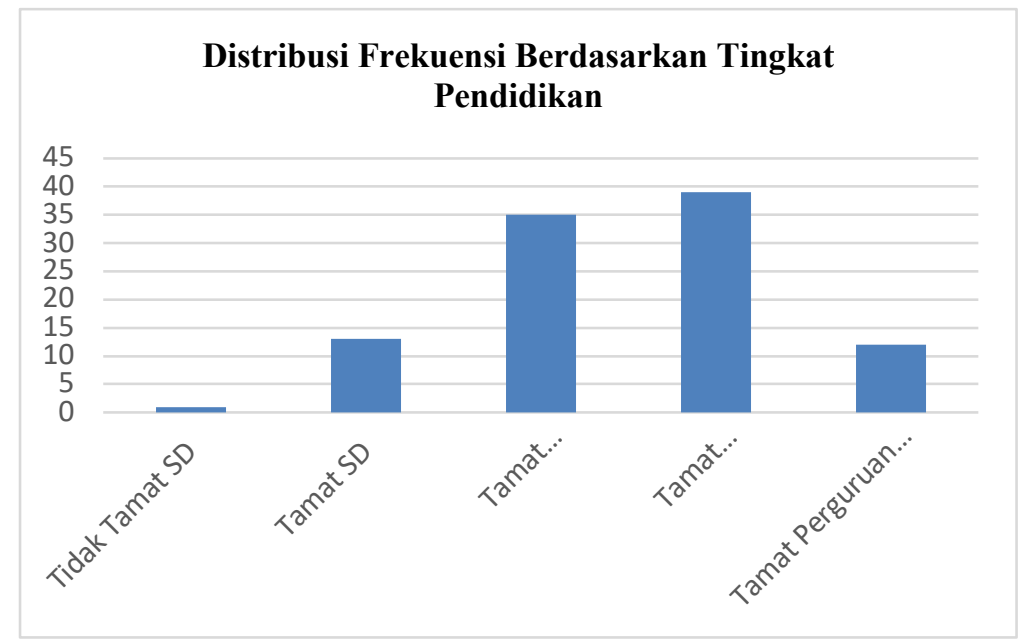

Gambar 1. Distribusi Frekuensi Berdasarkan Tingkat Pendidikan

\section{B. Pengetahuan Mengenai Pengelolaan Sampah Rumah Tangga}

Berdasarkan hasil wawancara dengan menggunakan keusioner tentang tingkat pengetahuan responden mengenai pengelolaan sampah rumah tangga dapat dilihat pada Tabel 2 berikut: 
Tabel 2. Distribusi Frekuensi Pengetahuan Responden Mengenai Pengelolaan Sampah Rumah Tangga

\begin{tabular}{cccc}
\hline Kategori & Interval Skor & Frekuensi & Persentase \\
\hline Sangat Rendah & $0-3$ & 0 & $0 \%$ \\
\hline Rendah & $4-6$ & 13 & $1 \%$ \\
\hline Sedang & $7-9$ & 33 & $33 \%$ \\
\hline Tinggi & $10-12$ & 35 & $35 \%$ \\
\hline Sangat Tinggi & $13-15$ & 19 & $19 \%$ \\
\hline Total & & 100 & $100 \%$ \\
\hline
\end{tabular}

Sumber : Data Penelitian 2020

Berdasarkan data pada Tabel 2 dapat dijelaskan bahwa dari 100 responden, sebagian besar memiliki pengetahuan yang tinggi mengenai pengelolaan sampah rumah tangga yaitu sebesar 35\%, yang berpengetahuan sangat tinggi sebesar 19\%, yang berpengetahuan sedang sebesar 33\% serta yang berpengetahuan rendah sebesar 13\%. Berdasarkan tabel distribusi frekuensi pada Tabel 2 dapat disajikan dalam bentuk grafik histogram sebagai berikut:

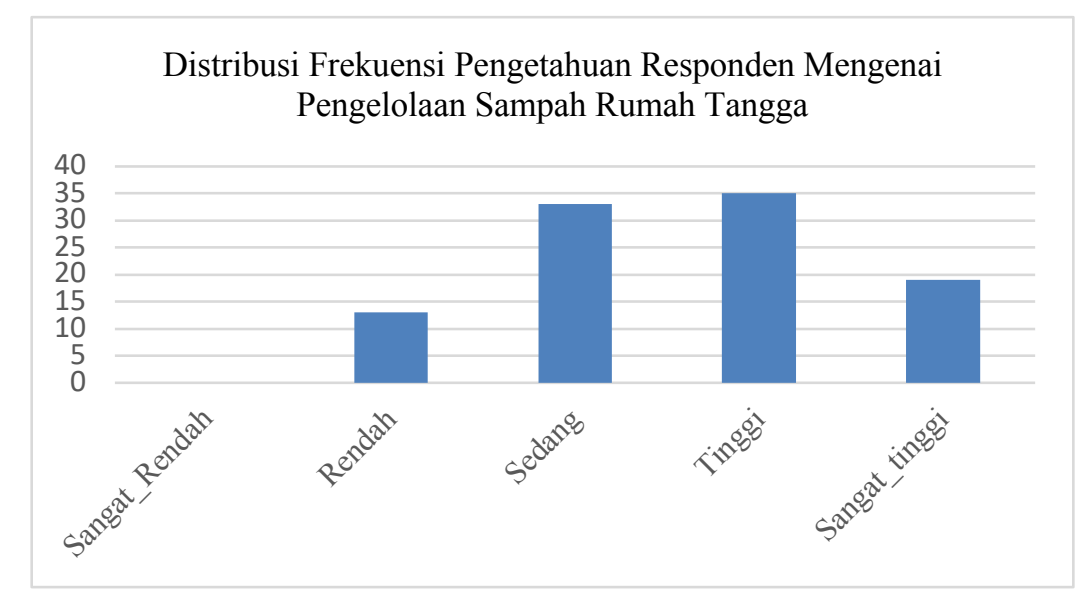

Gambar 2. Distribusi Frekuensi Pengetahuan Responden Mengenai Pengelolaan Sampah Rumah Tangga

C. Sikap Mengenai Pengelolaan Sampah Rumah Tangga

Hasil wawancara dengan menggunakan keusioner tentang sikap responden mengenai pengelolaan sampah rumah tangga dapat dilihat pada Tabel 3 berikut 
Tabel 3 Distribusi Frekuensi Sikap Responden Mengenai Pengelolaan Sampah Rumah Tangga

\begin{tabular}{cccc}
\hline Kategori & Interval Skor & Frekuensi & Persentase(\%) \\
\hline Kurang Baik & $32-45$ & 8 & $8 \%$ \\
\hline Baik & $46-59$ & 58 & $58 \%$ \\
\hline Sangat Baik & $60-73$ & 34 & $34 \%$ \\
\hline Total & & 100 & $100 \%$ \\
\hline
\end{tabular}

Sumber : Data Penelitian 2020

Berdasarkan data pada Tabel 3 dapat dijelaskan bahwa dari 100 responden, sebagian besar responden bersikap baik mengenai pengelolaan sampah rumah tangga yaitu sebesar $58 \%$, sangat baik sebesar 34\% dan sisanya bersikap kurang baik yaitu sebesar $8 \%$.

Berdasarkan tabel distribusi frekuensi pada Tabel 3 dapat disajikan dalam bentuk grafik histogram sebagai berikut:

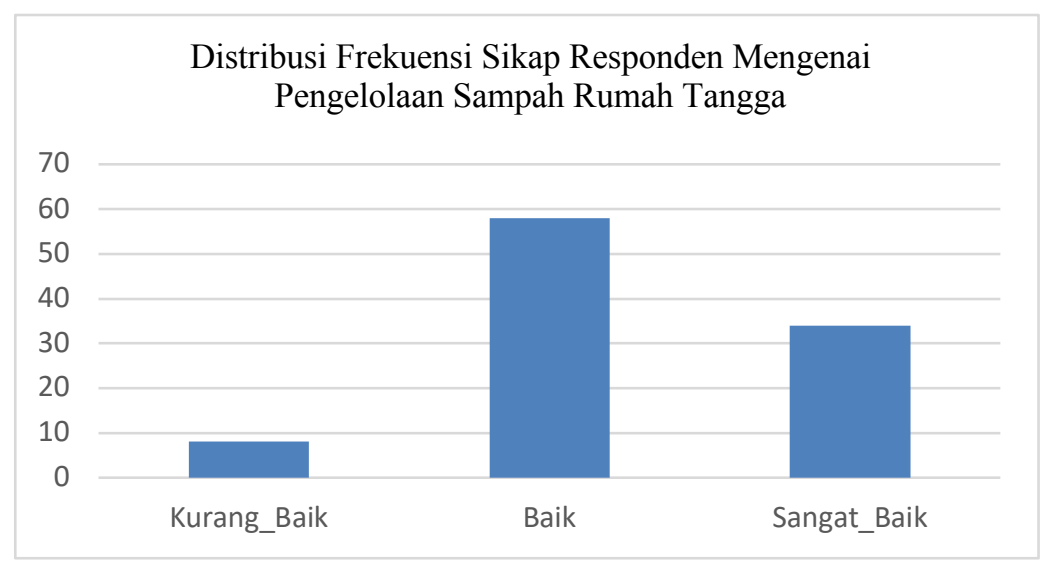

Gambar 3 Distribusi Frekuensi Sikap Responden Mengenai Pengelolaan Sampah Rumah Tangga

\section{Hubungan Pengetahuan, Sikap, Dan Tingkat Pendidikan terhadap Perilaku Mengenai Pengelolaan Sampah Rumah Tangga}

Berdasarkan pengujian hipotesis yang telah dilakukan, $H_{0}$ ditolak dan $H_{1}$ diterima. Hal ini menunjukkan bahwa Pengetahuan, sikap, dan tingkat pendidikan secara bersamasama berpengaruh terhadap perilaku mengenai pengelolaan sampah rumah tangga di wilayah Kecamatan Rantepao Kabupaten Toraja Utara. Besarnya pengaruh pengetahuan, sikap, dan tingkat pendidikan secara bersama-sama berpengaruh terhadap perilaku mengenai pengelolaan sampah rumah tangga dapat dilihat dari nilai koefisien determinasi $\left(R^{2}\right)$. Berdasarkan hasil perhitungan diperoleh angka $R^{2}$ (R_Square) sebesar 0,689 atau $(68,9 \%)$. Hal ini menunjukkan bahwa persentase sumbangan pengaruh pengetahuan, sikap, dan tingkat pendidikan terhadap perilaku mengenai pengelolaan sampah rumah tangga di wilayah Kecamatan Rantepao Kabupaten Toraja Utara sebesar 68,9\%. Semakin tinggi tingkat pendidikan dan pengetahuan mengenai pengelolaan sampah rumah tangga serta 
sikap positif yang tinggi akan miningkatkan kepedulian masyakat agar lebih sering mengelolah sampah rumah tangga, sehingga dapat membantuh pemerintah dalam pengelolaan sampah dan mengurangi pencemaran lingkungan.

\section{KESIMPULAN}

Terdapat hubungan yang signifikan antara sikap mengenai pengelolaan samapah rumah tangga dengan perilaku pengelolaan sampah rumah tangga di wilayah Kecamatan rantepao Kabupaten Toraja Utara. Semakain positif sikap mengenai pengelolaan sampah maka perilaku pengelolaan sampah rumah tangga juga semakin sering dilakukan.

Terdapat hubungan yang signifikan antara pengetahuan mengenai pengelolaan samapah rumah tangga dengan perilaku pengelolaan sampah rumah tangga di wilayah Kecamatan Rantepao Kabupaten Toraja Utara. Semakain baik pengetahuan mengenai pengelolaan sampah maka perilaku pengelolaan sampah rumah tangga juga semakin sering dilakukan.

Terdapat perbedaan yang signifikan perilaku pengelolaan sampah rumah tangga di wilayah Kecamatan rantepao Kabupaten Toraja Utara berdasarkan tingkat pendidikan. Responden yang tamat SMA/Sederajat ke atas lebih sering melakukan pengelolaan sampah rumah tangga dibandingkan dengan responden yang tamat SMP/Sederajat ke bawah.

\section{Referensi}

Adnani, H. 2009. Perilaku Petugas Pengumpul Sampah Untuk Melindungi Dirinya Dari Penyakit Bawaan Sampah Di Wilayah Patangpuluhan Yogyakarta Tahun 2009. Jurnal Kesmas UAD, 144-152.

Peraturan Pemerintah Republik Indonesia No. 81 Tahun 2012 Tentang Pengelolaan Sampah Rumah Tangga dan Sampah Sejenis Sampah Rumah Tangga

Prof. Enri Damanhuri, Dr. Tripadmi. 2010. Diktat Kuliah Tl-3104 Pengelolaan Sampah. Itb.

SNI 19-2454-2002. Tata Cara Teknik Operasional Sampah Perkotaan.

Sudrajat. (2006). Mengelola Sampah Kota: Solusi Mengatasi Masalah Sampah Kota dengan Manajemen Terpadu dan Mengolahnya Menjadi Energi Listrik \& Kompos. Depok: Penebar Swadaya.

Sugiyono, 2011, Metode Penelitian Kuantitatif, Kualitatif dan R\&D, Bandung : Alfabeta. 